\title{
ISOLASI DAN IDENTIFIKASI CENDAWAN YANG BERASOSIASI DENGAN PENYAKIT MATI PUCUK PADA BIBIT JABON (Anthocephalus cadamba (Roxb.) Miq)
}

\section{Isolation and Identification of Fungi Associated with Dieback Disease of Jabon Seedling (Anthocephalus cadamba (Roxb.) Miq)}

\author{
Ai Rosah Aisah ${ }^{1}$, Bonny P.W. Soekarno ${ }^{2}$, dan/and Achmad ${ }^{3}$ \\ ${ }^{1}$ Balai Pengkajian Teknologi Pertanian (BPTP) Nusa Tenggara Barat \\ J1. Raya Peninjauan Narmada, Lombok Barat 83371, Nusa Tenggara Barat, Indonesia \\ Telp. +62-370-671312; Fax. +62-370-671620 \\ ${ }^{2}$ Departemen Proteksi Tanaman, Fakultas Pertanian, Institut Pertanian Bogor \\ Jl. Lingkar Kampus IPB, Dramaga, Bogor 16680, Jawa Barat, Indonesia \\ Telp. +62-251-8629364; Fax. +62-251-8629362 \\ ${ }^{3}$ Departemen Silvikultur, Fakultas Kehutanan, Institut Pertanian Bogor \\ Jl. Lingkar Kampus IPB, Dramaga, Bogor 16680, Jawa Barat, Indonesia \\ Telp. +62-251-8626806; Fax. +62-251-8626886 \\ Email: arosfito10@gmail.com ${ }^{1}$
}

Tanggal diterima: 20 November 2014; Tanggal direvisi: 26 Oktober 2015; Tanggal disetujui: 11 November 2015

\begin{abstract}
Dieback diseases are often found attacking jabon seedlings in the nursery and potentially lead to seedling deaths. This study was aimed to obtain and identify the fungal isolates associated with dieback disease of jabon seedlings and determine the causative pathogens of dieback diseases. 25 fungal were isolated from diseased seedlings, consisted of Botryodiplodia spp., Fusarium spp., Colletotrichum sp., Curvularia sp., Pestalotiopsis sp., and sterile mycelia. The suspected fungus as the cause of dieback diseases on jabon seedlings were Botryodiplodia spp.
\end{abstract}

\section{Keywords: Botryodiplodia spp., morphological characters, nursery}

\begin{abstract}
ABSTRAK
Penyakit yang sering ditemui menyerang bibit jabon di areal persemaian dan berpotensi menyebabkan kematian terhadap bibit adalah mati pucuk. Penelitian ini bertujuan untuk memperoleh dan mengidentifikasi isolat cendawan yang berasosiasi dengan penyakit mati pucuk pada bibit jabon serta menentukan patogen penyebab mati pucuk tersebut. Jumlah isolat yang diperoleh dari isolasi tanaman sakit yaitu sebanyak 25 isolat cendawan, terdiri dari Botryodiplodia spp., Fusarium spp., Colletotrichum sp., Curvularia sp., Pestalotiopsis sp., dan miselium steril. Cendawan yang diduga sebagai penyebab mati pucuk pada bibit jabon adalah Botryodiplodia spp.
\end{abstract}

Kata kunci: Botryodiplodia spp., karakter morfologi, persemaian

\section{PENDAHULUAN}

Jabon (Anthocephalus cadamba (Roxb.) Miq) merupakan tanaman asli Indonesia yang saat ini tengah dikembangkan dan dibudidayakan. Tanaman ini dapat memberikan keuntungan baik secara ekologi maupun ekonomi. Oleh sebab itu, jenis tersebut banyak diminati oleh masyarakat. Secara ekologi, jabon dapat digunakan untuk kegiatan penghijauan atau reklamasi areal bekas tambang (Mansur \& Tuheteru, 2010). Penanaman jabon di areal bekas tambang telah dilakukan di pertambangan batubara PT Kaltim Prima Coal dengan hasil persen tumbuh sebesar $85-100 \%$
(Safriati, 2012). Secara ekonomi, jabon dapat dijadikan bahan investasi sebagai bahan baku industri, misalnya industri kayu lapis. Salah satu industri yang menggunakan kayu jabon sebagai bahan baku kayu lapis adalah PT Kutai Timber Indonesia yang memiliki kebutuhan bahan baku kayu sebanyak $25.000 \mathrm{~m}^{3} /$ bulan (Wiguna \& Yajri, 2010).

Permintaan pasar terhadap kayu jabon akan mengalami peningkatan seiring dengan perkembangan industri kayu di Indonesia. Pengembangan tanaman jabon dalam skala luas menuntut tersedianya bibit jabon berkualitas dalam jumlah banyak. Usaha penyediaan bibit jabon dalam 
jumlah banyak berpotensi menimbulkan gangguan penyakit pada tahap semai, karena bibit jabon dalam jumlah banyak berpotensi menjadi inang bagi patogen. Selain itu, kondisi bibit pada fase semai masih relatif rentan terhadap gangguan penyakit. Gangguan penyakit merupakan salah satu hambatan dalam proses regenerasi tanaman hutan, karena dapat mengurangi kuantitas dan kualitas bibit.

Sampai saat ini, gangguan penyakit pada tanaman jabon di areal persemaian di antaranya adalah penyakit bercak daun yang disebabkan Colletotrichum sp. (Anggraeni, 2009) dan penyakit mati pucuk yang disebabkan Rhizoctonia solani Kuhn. (Rahman et al., 1997). Berdasarkan pengamatan pada 5 lokasi persemaian di sekitar kampus IPB Dramaga, gejala penyakit yang sering ditemui menyerang bibit jabon adalah mati pucuk.

Penyakit mati pucuk dapat terjadi pada banyak tanaman dan disebabkan oleh satu atau beberapa cendawan patogen. Selain itu, penyakit mati pucuk dapat menyerang tanaman kayu dan semak, dan dapat terjadi baik di areal pertanaman maupun persemaian (Douglas, 2009; Rahman et al., 1997). Contoh serangan penyakit mati pucuk pada fase semai di antaranya terjadi pada tanaman karet (Hevea brasiliensis Müll. Arg.) yang disebabkan oleh Botryodiplodia theobromae Pat., keora (Sonneratia apetala Buch.Ham.) disebabkan oleh Chaetomella raphigera Swift., dan ash (Fraxinus spp.) disebabkan oleh Hymenoscyphus pseudoalbidus V. Queloz (Rahman et al., 1997; Kirisits et al., 2012).

Penyakit mati pucuk pada bibit jabon dapat menimbulkan masalah yang serius, karena selain dapat menimbulkan kerusakan pada berbagai tingkatan umur bibit jabon, penyakit ini juga berpotensi menyebabkan kematian pada bibit dengan persentase 5-15\% (Cahyadi E., 27 Maret 2013, komunikasi pribadi). Oleh karena itu, perlu dilakukan studi lebih lanjut untuk mengisolasi dan mengidentifikasi cendawan yang berasosiasi dengan gejala mati pucuk pada bibit jabon. Tujuan penelitian adalah untuk memperoleh dan mengidentifikasi isolat cendawan yang berasosiasi dengan penyakit mati pucuk pada bibit jabon serta menentukan patogen penyebab primer penyakit mati pucuk pada bibit jabon.

\section{METODOLOGI}

\section{A. Tempat dan Waktu}

Penelitian dilakukan di Laboratorium Mikologi (Departemen Proteksi Tanaman, Fakultas Pertanian, Institut Pertanian Bogor) untuk kegiatan isolasi dan identifikasi serta di rumah paranet Bagian Perlindungan Hutan (Departemen Silvikultur, Fakultas Kehutanan, Institut Pertanian Bogor) untuk kegiatan uji postulat Koch. Penelitian dilaksanakan mulai bulan Desember 2012 sampai dengan Juni 2013.

\section{B. Bahan dan Alat}

Bahan yang digunakan dalam penelitian ini adalah bibit jabon (tinggi $10-40 \mathrm{~cm}$ ) yang memperlihatkan gejala mati pucuk yang diambil dari 5 lokasi persemaian di sekitar Kampus Institut Pertanian Bogor (IPB) Dramaga (2 persemaian berlokasi di daerah Situ Gede, 1 persemaian di daerah Jampang, 1 persemaian di daerah Cilubang, dan 1 persemaian berlokasi di Fakultas Kehutanan, Institut Pertanian Bogor), bibit jabon sehat umur \pm 4 bulan dari penyapihan, media PDA (Potato Dextrose Agar), alkohol 70\%, larutan $\mathrm{NaOCl} 1 \%$, dan akuades. Adapun alat yang digunakan dalam penelitian ini yaitu cawan petri, erlenmeyer, laminar air flow, dan mikroskop cahaya.

\section{Metode}

Penelitian ini terdiri atas 4 kegiatan, yaitu: (1) pengamatan gejala dan pengambilan sampel anakan yang memperlihatkan gejala penyakit mati pucuk pada 5 lokasi persemaian di sekitar kampus IPB Dramaga, (2) isolasi cendawan dari jaringan tanaman sakit (memperlihatkan gejala mati pucuk), (3) identifikasi isolat cendawan berdasarkan karakter morfologi, dan (4) uji postulat Koch.

\section{Pengamatan gejala dan pengambilan sam- pel anakan jabon}

Sampel anakan adalah bibit jabon yang memperlihatkan gejala mati pucuk. Sampel anakan diambil dari 5 lokasi persemaian. Jumlah sampel anakan yang diambil dari lokasi persemaian yaitu sebanyak 2-3 tanaman sakit, kecuali pada lokasi persemaian Situ Gede-2 dan Jampang hanya diambil 1 sampel karena ketersediaan sampel anakan sakit relatif sedikit. Sampel anakan jabon yang terinfeksi penyakit mati pucuk kemudian dibawa ke laboratorium sebagai bahan untuk 
tahapan selanjutnya dalam penelitian.

\section{Isolasi cendawan dari jaringan tanaman sakit}

Sampel anakan jabon selanjutnya diisolasi. Kegiatan ini dilakukan berdasarkan metode Akrofi \& Amoah (2009). Langkah pertama, bagian tanaman yang memperlihatkan gejala sakit diambil dari sampel anakan dengan cara dipotong. Potongan jaringan kemudian disterilisasi permukaan dengan cara direndam dalam larutan $\mathrm{NaOCl} 1 \%$ selama \pm 2 menit, lalu dicuci dengan air steril sebanyak 3 kali, selanjutnya dikeringkan di atas kertas saring steril yang ada di dalam cawan petri. Setelah kering, jaringan anakan dipotong pada bagian setengah sakit, lalu dimasukkan ke dalam cawan petri berisi media PDA. Setiap cawan petri terdiri dari 3 potongan jaringan yang berasal dari 1 sampel anakan jabon. Potongan jaringan pada media PDA selanjutnya diinkubasi di bawah pencahayaan NUV (Near Ultra Violet) dengan periode 12 jam terang dan 12 jam gelap pada suhu ruang untuk memicu sporulasi cendawan. Koloni cendawan yang tumbuh dari potongan jaringan kemudian dimurnikan dan diperbanyak pada media PDA. Isolat cendawan yang diperoleh selanjutnya digunakan sebagai bahan untuk kegiatan identifikasi.

\section{Identifikasi isolat cendawan}

Kegiatan identifikasi dilakukan berdasarkan karakter morfologi isolat. Hal ini dilakukan dengan cara mengamati karakter makroskopis dan mikroskopis isolat cendawan yang meliputi warna dan tekstur koloni, serta bentuk dan ukuran konidia. Identifikasi dilakukan berdasarkan buku kunci identifikasi Watanabe (1994) dan Barnet \& Hunter(1998).

\section{Uji Postulat Koch}

Uji postulat Koch bertujuan untuk membuktikan bahwa isolat yang diperoleh merupakan agen penyebab dari gejala penyakit yang diamati. Kegiatan ini terdiri atas inokulasi isolat pada sampel anakan, reisolasi jaringan tanaman yang memperlihatkan gejala, dan identifikasi isolat hasil reisolasi.

Sampel anakan yang digunakan untuk inokulasi merupakan bibit jabon umur \pm 4 bulan dari penyapihan. Setiap isolat cendawan diinokulasikan terhadap 5 bibit jabon dan setiap bibit diberi 2 perlakuan, yaitu dilukai dan tidak dilukai. Inokulasi dilakukan pada sore hari dengan mengguna- kan 2 metode, yaitu injeksi suspensi konidia dan penempelan blok agar. Penentuan metode inokulasi yang digunakan bergantung pada kemampuan isolat cendawan untuk bersporulasi. Perlakuan pelukaan pada bibit jabon dilakukan dengan bantuan jarum suntik steril. Bagian tanaman yang akan diinokulasi sebelumnya disterilisasi permukaan dengan alkohol $70 \%$.

Penyiapan sumber inokulum dan teknik inokulasi untuk metode injeksi suspensi konidia dilakukan berdasarkan metode Ahmad et al. (2012) dengan modifikasi pada masa inkubasi isolat dan kepadatan konidia yang digunakan sebagai sumber inokulum. Sumber inokulum diperoleh dengan cara menambahkan $10 \mathrm{ml}$ akuades steril pada kultur isolat cendawan umur 10 hari. Permukaan kultur isolat selanjutnya dikikis secara perlahan dengan menggunakan spatula gelas (glass rod), kemudian suspensi disaring dengan kertas saring whatman no. 1. Suspensi konidia yang diperoleh kemudian dihitung kepadatannya dengan haemocytometer, lalu sebanyak $0,1 \mathrm{ml}$ suspensi konidia dengan kepadatan $\pm 1 \times 10^{6}$ konidia/ml diinjeksikan pada bagian daun (dilukai dan tidak dilukai) dan batang bagian atas bibit jabon. Sebagai kontrol, bibit jabon diinjeksi dengan akuades steril. Bibit jabon kemudian ditutup dengan plastik dan dibuka setelah muncul gejala. Evaluasi gejala penyakit dilakukan setiap hari selama 14 hari setelah inokulasi.

Penyiapan sumber inokulum dan teknik inokulasi untuk metode penempelan blok agar dilakukan berdasarkan metode Ismail et al. (2012) dengan modifikasi pada masa dan tempat inkubasi tanaman. Sumber inokulum diperoleh dengan cara memotong bagian ujung koloni isolat cendawan umur 7 hari dengan cork borer (Ø $7 \mathrm{~mm})$. Setelah itu, potongan agar ditempel pada batang bagian atas (dilukai dan tidak dilukai) bibit jabon. Sebagai kontrol, bagian batang ditempeli dengan blok agar tanpa koloni isolat cendawan. Potongan blok agar yang ditempel pada bagian batang selanjutnya ditutup dengan kapas lembab dan alumunium foil selama \pm 7 hari atau sampai muncul gejala. Evaluasi gejala penyakit dilakukan dengan cara yang sama seperti metode injeksi suspensi konidia.

Gejala penyakit yang muncul pada titik inokulasi selanjutnya direisolasi, kemudian isolat hasil reisolasi diidentifikasi dan dibandingkan dengan isolat sebelumnya. Apabila isolat cendawan yang diinokulasikan menghasilkan gejala yang identik dengan gejala mati pucuk dan teridentifikasi sebagai cendawan yang identik 
dengan isolat sebelumnya, maka cendawan tersebut merupakan agen penyebab dari penyakit mati pucuk.

\section{HASIL DAN PEMBAHASAN}

\section{A. Gejala Penyakit Mati Pucuk pada Tanam- an Jabon}

Berdasarkan pengamatan gejala penyakit di lokasi persemaian, bibit jabon yang terinfeksi penyakit mati pucuk memiliki gejala nekrosis pada batang bagian tengah atau atas dan daun. Nekrosis merupakan kerusakan atau kematian sel-sel, jaringan atau organ tumbuhan. Gejala nekrosis yang berkembang pada bagian batang dapat menyebabkan batang mengering dan tidak mampu menopang bagian atas tanaman, sehingga tanaman terkulai (Gambar 1a). Sementara itu, gejala nekrosis pada bagian daun dapat menyebabkan daun kering dan meng-gulung (Gambar 1b). Selain nekrosis, penyakit mati pucuk dapat diawali dengan gejala layu dan mengerutnya bagian batang (Gambar 1c). Meskipun batang masih terlihat berwarna hijau, tapi batang menjadi lebih sukulen dari kondisi normal sehingga tidak mampu menopang bagian atas tanaman.

Gejala penyakit mati pucuk pada bibit jabon ditemukan mulai dari bibit muda (bentuk sosisan dengan umur \pm 2 bulan) sampai dengan bibit siap tanam (umur 5-6 bulan) (Gambar 2). Bagian atas atau ujung tanaman biasanya lebih cepat mengalami nekrosis jika dibandingkan bagian pangkal tanaman. Gejala penyakit dapat terhambat atau berhenti pada bagian batang yang telah mengeras, sehingga bibit yang telah memiliki batang cukup keras terkadang masih bisa bertahan hidup dengan cara menghasilkan tunas baru. Bagian batang yang sudah berkayu terlihat berwarna kehitaman apabila dipotong secara melintang (Gambar 2e). Adapun kejadian penyakit mati pucuk pada 5 lokasi pengamatan memiliki persentase berkisar $1-15 \%$.

Gejala penyakit pada tanaman merupakan bentuk penyimpangan baik morfologi atau fisiologi sebagai respon dari adanya gangguan patogen (Widyastuti et al., 2005). Respon yang dihasilkan tanaman berbeda-beda, bergantung pada interaksi antara tanaman inang dan patogennya.

Penyakit mati pucuk memiliki gejala yang relatif sama pada beberapa jenis tanaman inang, yaitu berupa matinya bagian ujung tanaman. Khanzada et al. (2004) melaporkan bahwa penyakit mati pucuk pada tanaman mangga yaitu berupa matinya bagian ranting, daun menggulung dan mengering yang selanjutnya gugur. Sementara itu, gejala mati pucuk pada bibit tanaman ash dapat diawali dengan adanya nekrosis pada bagian kulit atau batang yang selanjutnya dapat menyebar ke bagian ranting dan mematikan bagian tersebut (Kirisits et al., 2012).

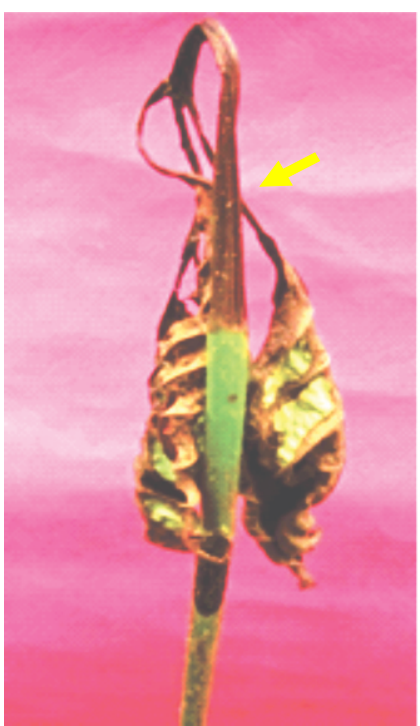

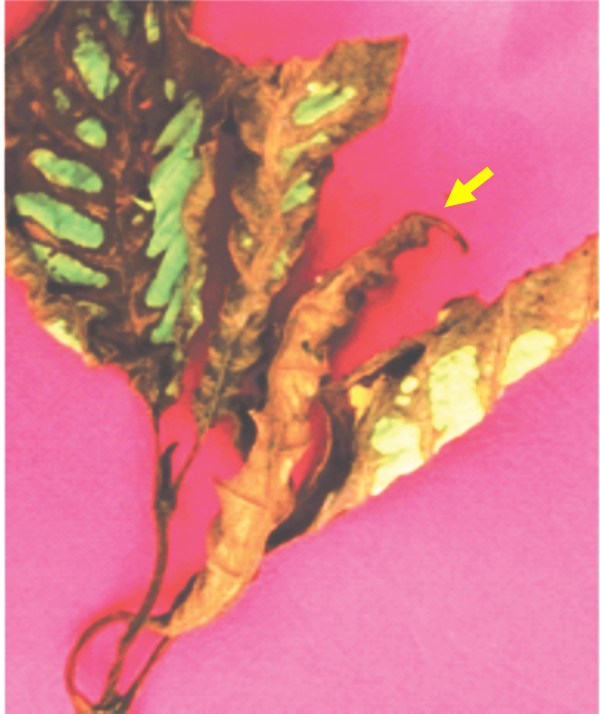

b

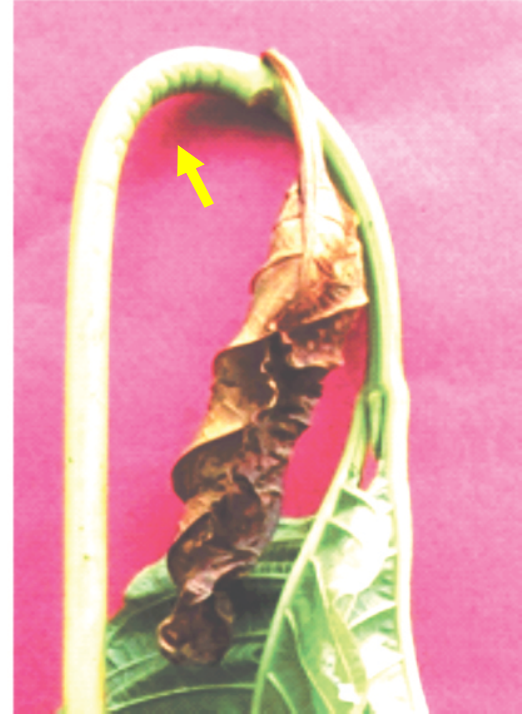

c

Sumber (Source): Dokumentasi pribadi (Personal documentation) (2012)

Gambar (Figure) 1. Gejala penyakit mati pucuk pada bibit jabon di lokasi persemaian: a) nekrosis pada batang, b) nekrosis pada daun, dan c) batang mengerut (Dieback disease symptoms of jabon seedling at the nursery locations: a) necrotic of stem, b) necrotic of leaves, and c) stem shrivel) 
Bibit jabon yang mengalami mati pucuk juga memiliki gejala berupa kematian pada bagian ujung tanaman. Kematian jaringan pada ujung tanaman ini diawali dengan adanya nekrosis pada bagian batang atau daun. Gejala nekrosis yang diawali dari bagian batang umumnya menyebar ke arah daun dengan menginfeksi bagian tulang daun utama terlebih dahulu. Setelah tulang daun utama terinfeksi, selanjutnya daun mengering dan menggulung, lalu gugur. Selain menyebar ke bagian daun, nekrosis pada batang juga dapat menyebar ke batang bagian bawah. Bagian batang yang mulai terinfeksi, pada awalnya terlihat mengerut, kemudian mengering, lalu mati. Gejala pada batang dapat terhambat atau terhenti pada bagian yang sudah berkayu, sehingga tanaman masih mampu bertahan hidup. Tanaman dengan kondisi seperti ini biasanya mengeluarkan tunas baru sehingga terbentuk percabangan.

Gejala mati pucuk pada bibit jabon juga dapat diawali dengan adanya kerutan pada bagian batang. Tanaman pada umumnya terlihat terkulai karena bagian batang tidak mampu menopang bagian atas tanaman. Batang yang terinfeksi selanjutnya mengalami penyusutan sehingga apabila ditekan akan terasa kosong atau hampa. Gejala kerutan yang menyebar ke bagian daun dapat mengakibatkan daun berwarna pucat dan layu.

Perkembangan penyakit di areal persemaian dapat dipengaruhi oleh beberapa faktor, di anta- ranya adalah aktivitas budi daya. Adanya kegiatan pemindahan tanaman secara periodik di areal persemaian dapat menimbulkan luka mekanis pada tanaman. Luka tersebut tidak hanya dapat menyebabkan tanaman stress, tetapi juga dapat menciptakan titik masuk bagi patogen untuk menginfeksi jaringan tanaman. Selain itu, penempatan tanaman dengan jarak yang cukup rapat dapat menciptakan kondisi lembab di sekitar tanaman. Oleh karena itu, dengan terciptanya kondisi lingkungan yang lembab, adanya luka mekanis, dan kondisi tanaman yang stress dapat memudahkan patogen untuk menginfeksi inang.

Berdasarkan pengamatan gejala di lokasi persemaian, dapat diketahui bahwa patogen menginfeksi bagian tanaman yang lebih sukulen terlebih dahulu. Hal ini dapat dilihat dari gejala penyakit yang berkembang relatif cepat menuju bagian atas tanaman dibandingkan menuju bagian pangkal. Jaringan pangkal batang relatif lebih keras jika dibandingkan dengan jaringan bagian ujung tanaman. Pangkal batang yang keras telah mengalami proses lignifikasi, sehingga patogen tidak mudah menginfeksi tanaman. Novaes et al. (2010) menyatakan bahwa sifat fisik dan kimia lignin bertindak sebagai barrier dalam melawan serangan hama dan penyakit. Kandungannya di dalam tanaman bervariasi pada jaringan yang berbeda.
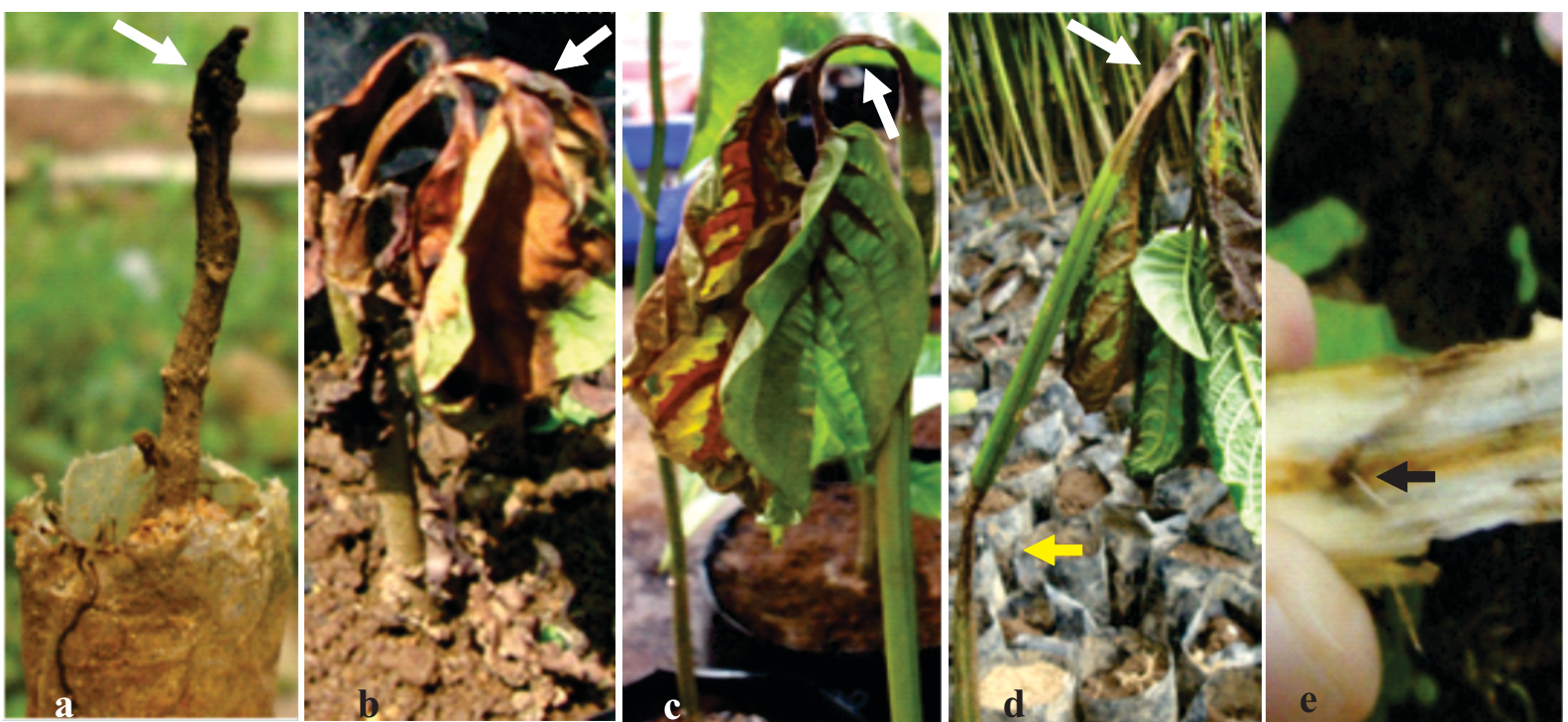

Sumber (Source): Dokumentasi pribadi (Personal documentation) (2012)

Gambar(Figure) 2. Bibit jabon yang terserang penyakit mati pucuk pada beberapa tingkatan umur: a) nekrosis pucuk pada bibit \pm 2 bulan, $b$-d) nekrosis batang dan daun pada bibit \pm 3 , 4, dan 5 bulan secara berturut-turut, dan e) warna kehitaman pada batang bibit yang telah berkayu (Dieback diseased jabon seedling at several age levels: a) shoot necrotic of \pm 2 months old seedling, $b$-d) stem and leaf necrotics of $\pm 3,4$, and 5 months old seedling respectively, and e) blackish color on the woody seedling stem) 


\section{B. Isolasi dan Identifikasi Cendawan}

Sebanyak 25 isolat cendawan berhasil diisolasi dari tanaman sakit yang menunjukkan gejala nekrosis pada bagian ujung tanaman. Berdasarkan pengamatan warna koloni pada umur 2 minggu, isolat-isolat tersebut dapat dikelompokkan menjadi 4, yaitu kelompok isolat berwarna putih, putih keabuan, putih keunguan, dan abu-abu kehitaman. Hasil identifikasi berdasarkan karakter morfologi, isolat-isolat tersebut diketahui sebagai Botryodiplodia spp., Fusarium spp., Colletotrichum sp., Curvularia sp., Pestalotiopsis sp., dan miselium steril. Isolat Botryodiplodia spp. diperoleh sebanyak 9 isolat dari 4 lokasi, Fusarium spp. diperoleh 9 isolat dari 4 lokasi, Colletotrichum sp. diperoleh 1 isolat dari 1 lokasi, Curvularia sp. dan Pestalotiopsis sp. masing-masing diperoleh 1 isolat dari 1 lokasi yang sama, dan miselium steril diperoleh 4 isolat dari 3 lokasi (Tabel 1). Isolat Botryodiplodia dan Fusarium yang diperoleh diduga lebih dari 1 spesies jika dilihat berdasarkan karakter morfologi koloni.

Pengamatan makroskopis (Gambar 3-A1) menunjukkan bahwa koloni isolat cendawan $\mathrm{Bo}$ tryodiplodia spp. secara umum memiliki warna putih pada permukaan atas yang selanjutnya akan berubah menjadi abu-abu atau hijau kehitaman. Sementara pada bagian bawah petri, koloni memiliki warna hijau kehitaman atau hitam. Morfologi koloni miselium Botryodiplodia sp. adalah fluffy dan rugose. Isolat memiliki pertumbuhan radial yang cepat, yaitu dapat memenuhi cawan petri $(\varnothing 9 \mathrm{~cm})$ setelah 2-4 hari masa inkubasi. Sementara itu, berdasarkan pengamatan mikroskopis isolat Botryodiplodia spp. memiliki hifa bersekat, hialin pada hifa muda dan berwarna coklat pada hifa tua. Konidia pada awalnya hialin dan tidak bersekat, kemudian berubah menjadi berwarna kecoklatan dan memiliki 1 sekat. Konidia berbentuk ellipsoid atau ovoid dengan ukuran 26-32 x 13-17 $\mu \mathrm{m}$ (Gambar 3-B1).

Koleksi isolat Fusarium spp. menunjukkan warna putih (Gambar 3-A2) atau putih keunguan pada permukaan bagian atas dan bawah media dalam cawan petri. Warna ungu yang terlihat pada bagian bawah petri memiliki pola warna yang berbeda, yaitu warna ungu pada bagian tengah koloni miselium dan warna ungu yang diselingi oleh warna putih. Morfologi koloni miselium Fusarium spp. adalah velvety dan verrucose. Koloni isolat dapat memenuhi cawan petri setelah 7-10 hari masa inkubasi. Konidia Fusarium spp. terdiri atas mikrokonidia bersekat dan tidak bersekat serta makrokonidia dengan sekat 1-4. Mikrokonidia memiliki bentuk yang beragam, yaitu reniform, allantoid, oval, ovoid, dan fusiform dengan ukuran 6-10 x 2-3 $\mu \mathrm{m}$. Adapun makrokonidia berbebntuk lunate atau filiform dengan ukuran sekitar 16-43 x 3-4 $\mu \mathrm{m}$ (Gambar 3-B2). Klamidospora hialin, tunggal atau berpasangan, terminal atau interkalar, dan memiliki ukuran sekitar $8 \mu \mathrm{m}$.

Koloni isolat Colletotrichum sp. memiliki warna koloni putih pada permukaan bagian atas dan putih keabuan pada bagian bawah petri (Gambar 3-A3). Morfologi koloni yaitu verrucose, cottony. Disamping itu, koloni memi-liki pertumbuhan radial sedang dengan 6 hari masa inkubasi dapat memenuhi cawan petri. Konidia berbentuk oblong dengan ukuran 14-16 x 4-5 $\mu \mathrm{m}$ (Gambar 3-B3).

Koloni isolat Pestalotiopsis sp. berwarna putih pada permukaan bagian atas dan putih kekuningan pada bagian bawah petri (Gambar 3A4). Morfologi koloni verrucose, velvety, dan isolat dapat memenuhi cawan petri setelah 13 hari masa inkubasi. Konidia berwarna coklat, ber-sekat, berbentuk fusiform dengan ukuran

Tabel (Table) 1. Perolehan isolat cendawan berdasarkan lokasi pengambilan sampel tanaman jabon yang memperlihatkan gejala mati pucuk (Obtained fungal isolates based on locations of jabon plant samples showing dieback disease symptom)

\begin{tabular}{cllc}
\hline No & Isolat (Isolaates) & Lokasi persemaian (Location) & Jumlah Isolat \\
\hline 1 & Botryodiplodia spp. & $\begin{array}{l}\text { Situ Gede (1 dan 2), Jampang, Cilubang, Fakultas } \\
\text { Kehutanan IPB } \\
\text { Situ Gede1, Jampang, Cilubang, Fakultas }\end{array}$ & 9 \\
2 & Fusarium spp. & Kehutanan IPB & 9 \\
3 & Colletotrichum sp. & Cilubang & 1 \\
4 & Curvularia sp. & Situ Gede1 & 1 \\
5 & Pestalotiopsis sp. & Situ Gede1 & 1 \\
6 & Miselium steril & Situ Gede (1 dan 2) dan Fakultas Kehutanan IPB & 4 \\
\hline
\end{tabular}

Sumber (Source): Data primer penelitian (Primary data of research) (2013) 
25-27 x $5 \mu \mathrm{m}$, dan memiliki embelan pada kedua ujung konidia (Gambar 3-B4).

Isolat cendawan yang tidak menghasilkan struktur reproduksi merupakan miselium steril yang terdiri atas kumpulan hifa saja. Terdapat 4 isolat yang merupakan miselium steril dan keempat isolat ini memiliki warna koloni yang berbeda. Isolat pertama berwarna putih pada permukaan bagian atas dan putih kekuningan pada bagian bawah petri, isolat ke-2 berwarna putih, baik pada permukaan atas koloni maupun bagian bawah petri (Gambar 3-A5), isolat ke-3 dan ke-4 memiliki koloni berwarna gelap. Masing-masing koloni miselium isolat tersebut yaitu rugose, velvety, dapat memenuhi cawan petri setelah 4-11 hari masa inkubasi, dan lebar hifa berukuran sekitar 5-6 $\mu \mathrm{m}$ (Gambar 3-B5).

Isolat Curvularia sp. memiliki koloni berwarna gelap, baik pada bagian permukaan atas koloni maupun bagian bawah petri (Gambar 3-A6). Koloni isolat cendawan ini adalah umbonate, velvety, dan memenuhi cawan petri setelah 6 hari masa inkubasi. Konidia berbentuk inequilateral, berwarna cokelat, terdiri atas 2-4 sekat, dan berukuran 26-30 x 7-8 $\mu \mathrm{m}$ (Gambar 3-B6).

Hasil isolasi menunjukkan bahwa gejala penyakit mati pucuk berasosiasi dengan beberapa genus cendawan. Hal ini sesuai dengan penelitian Muehlbach et al. (2010) yang berhasil mendeteksi beberapa isolat cendawan seperti Lasio- diplodia theobromae (Pat.) Grifon \& Maubl., F. oxysporum Schlecht., Curvularia affinis Boedijn, dan Bipolaris sp. dari tanaman shisham (Dalbergia sissoo Roxb.) yang memperlihatkan gejala mati pucuk. Selain itu, Rajput et al. (2008) berhasil mengisolasi cendawan $F$. solani (Mart.) Sacc. dari tanaman shisham dengan gejala yang sama.

Cendawan yang sering muncul hampir di setiap lokasi penelitian adalah Botryodiplodia spp. dan Fusarium spp.. Kedua cendawan ini muncul pada 3 lokasi (Situ Gede1, Cilubang, dan Fakultas Kehutanan IPB) dan berhasil diisolasi dari sampel anakan yang sama. Selain itu, di lokasi persemaian Cilubang kedua cendawan tersebut berhasil diisolasi dengan Colletotrichum sp. dari sampel anakan yang sama. Jika dilihat berdasarkan lokasi pengambilan tanaman contoh, maka lokasi yang memiliki isolat beragam adalah lokasi persemaian Situ Gede 1. Lima dari 6 macam cendawan berhasil diisolasi dari sampel anakan jabon yang berasal dari lokasi tersebut. Hal ini diduga karena jenis tanaman yang tersedia di lokasi Situ Gede1 lebih banyak dan beragam jika dibandingkan dengan 4 lokasi lain. Sinaga (2006) menyatakan bahwa beberapa patogen terbatas pada spesies tunggal atau satu genus inang, sedangkan patogen lain memiliki kisaran inang yang luas. Oleh karena itu, semakin beragam tanaman yang tersedia di lokasi persemaian,
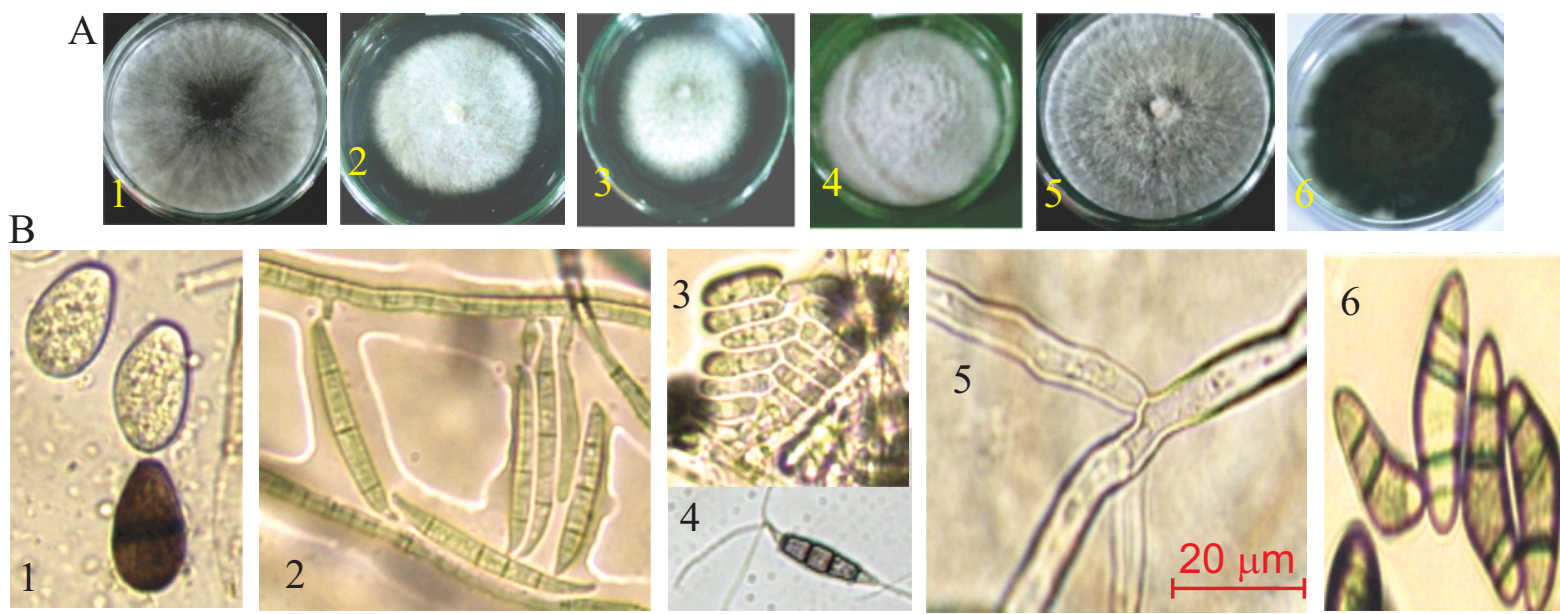

Sumber (Source): Dokumentasi pribadi (Personal documentation) (2013)

Gambar(Figure) 3. Penampilan makroskopis (A) dan mikroskopis (B) isolat cendawan yang diperoleh dari bibit jabon yang memperlihatkan gejala mati pucuk: koloni dan konidia Botryodiplodia spp. (A1,B1); Fusarium spp. (A2,B2); Colletotrichum sp. (A3, B3); Pestalotiopsis sp. (A4, B4); hifa steril (A5, B5); dan Curvularia sp. (A6, B6) (Macroscopic (A) and microscopic (B) appearances of fungal isolates gained from jabon seedling showing dieback disease symptom: colony and conidia of Botryodiplodia spp. (A1, B1); Fusarium spp. (A2, B2); Colletotrichum sp. (A3, B3); Pestalotiopsis sp. (A4, B4); sterile hyphae (A5, B5); and Curvularia sp. (A6, B6)) 
maka diduga akan beragam pula patogen yang dapat menginfeksi.

Lima dari 6 macam cendawan yang diperoleh merupakan patogen yang memiliki kisaran inang luas. Oleh sebab itu, sumber inokulum penyakit mati pucuk pada bibit jabon dapat berasal dari bibit jabon itu sendiri atau dari tanaman lain.

Selain jenis tanaman, faktor yang diduga mempengaruhi keragaman cendawan di areal persemaian adalah kultur teknis dan kondisi lingkungan persemaian. Kultur teknis meliputi metode penyemaian benih, pemupukan, penyiraman, pengaturan jarak antar tanaman, pemilihan jenis tanaman, penggunaan jenis media tanam, dan usaha pengendalian hama dan penyakit. Kegiatan-kegiatan tersebut dapat membantu introduksi dan penyebaran suatu mikroorganisme, sedangkan lokasi persemaian dapat mempengaruhi kondisi lingkungan, misalnya suhu udara dan kelembaban. Kondisi lingkungan merupakan salah satu komponen dari segitiga penyakit. Oleh karena itu, apabila kondisi lingkungan mendu-kung, maka patogen dapat menginfeksi tanaman inang dan menyebabkan penyakit.

Beberapa kultur teknis yang umum dilakukan di setiap persemaian lokasi penelitian adalah penggunaan bahan kimia untuk pengendalian hama dan penyakit, serta penggunaan kembali media tanah yang sebelumnya ditumbuhi tanaman sakit. Adapun kondisi lingkungan dari 5 lokasi persemaian cukup beragam jika dilihat berdasarkan tingkat ketinggian dan kondisi lingkungan sekitar persemaian, misalnya lingkungan sekitar lokasi persemaian merupakan pemukiman penduduk, ladang, sawah atau tegakan pohon. Hal ini dapat mempengaruhi penyebaran dan perkembangan penyakit.

\section{Uji Postulat Koch}

Gejala yang muncul setelah tanaman jabon diinokulasi adalah berupa nekrosis pada titik inokulasi. Nekrosis selanjutnya menyebar ke bagian lain sehingga bagian yang terinfeksi menjadi terlihat berwarna kecokelatan. Penyakit yang terus berkembang akan menyebabkan bagian atas tanaman terkulai dan kering.

Isolat yang mampu menghasilkan gejala pada tanaman jabon yang diinokulasi adalah Botryodiplodia spp., Fusarium spp., dan Colletotrichum sp. (Gambar 4). Isolat Botryodiplodia spp. secara umum dapat menghasilkan gejala pada bagian yang dilukai dan tidak dilukai, sedangkan isolat Fusarium spp. dan Colletotrichum sp. hanya pada bagian yang dilukai.

Inokulasi isolat Botryodiplodia spp. pada bagian batang menimbulkan gejala nekrosis setelah masa inkubasi 2-3 hari. Nekrosis cepat berkembang ke bagian atas tanaman, menyebabkan batang bagian atas dan daun menjadi berwarna kecokelatan dan selanjutnya mati. Nekrosis yang tidak berkembang umumnya hanya mengalami perubahan warna dari cokelat menjadi cokelat kehitaman dengan arah penyebaran melintang.

Inokulasi isolat Botryodiplodia spp. pada bagian batang menimbulkan gejala nekrosis setelah masa inkubasi 2-3 hari. Nekrosis cepat berkembang ke bagian atas tanaman, menyebabkan batang bagian atas dan daun menjadi berwarna kecokelatan dan selanjutnya mati. Nekrosis yang tidak berkembang umumnya hanya mengalami
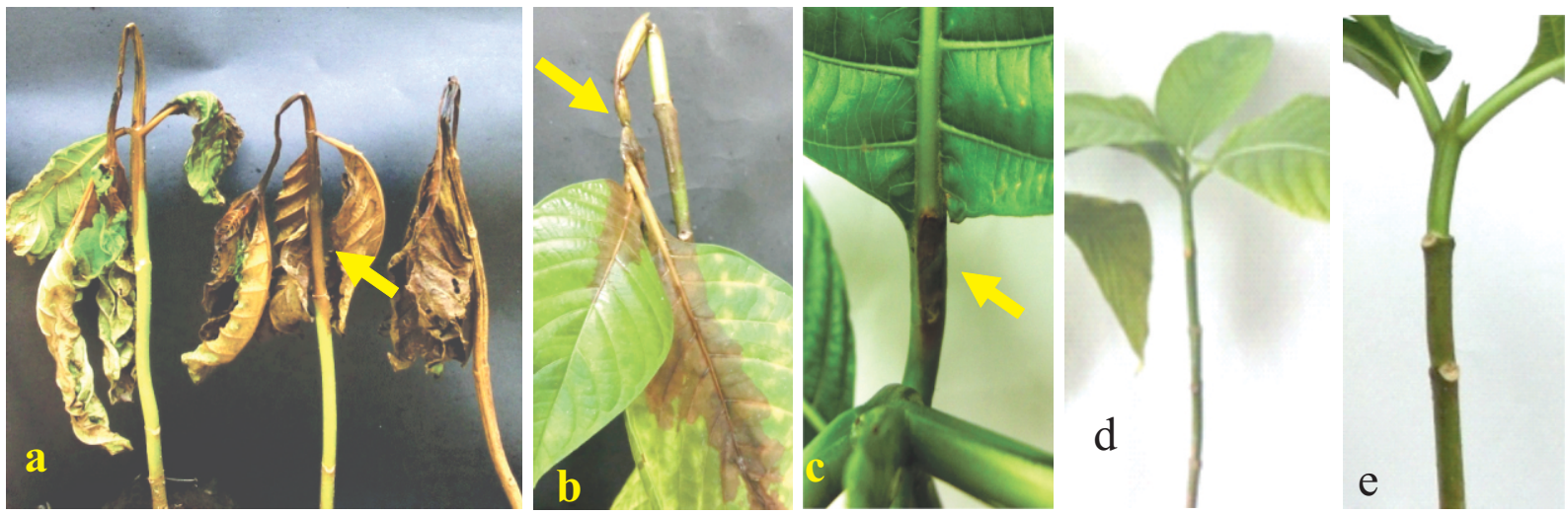

Sumber (Source): Dokumentasi pribadi (Personal documentation) (2013)

Gambar (Figure) 4. Gejala penyakit pada bibit jabon setelah inokulasi pada tahap postulat Koch: a) Botryodiplodia spp., b) Fusarium spp., c) Colletotrichum sp., d) miselium steril, dan e) kontrol (Symptom of diseases on jabon seedlings after inoculation of Koch's postulate stage: a) Botryodiplodia spp., b) Fusarium spp., c) Colletotrichum sp., d) sterile mycelia, and e) control) 
perubahan warna dari cokelat menjadi cokelat kehitaman dengan arah penyebaran melintang.

Inokulasi suspensi konidia Fusarium spp. pada bagian batang dan daun menimbulkan gejala yang berbeda, yaitu berupa busuk basah pada bagian batang, dan nekrosis atau gugur pada bagian daun. Masa inkubasi untuk menimbulkan gejala pada tanaman jabon, bervariasi antara satu isolat dengan isolat lainnya. Masa inkubasi yang cepat berkisar 3-4 hari, sedangkan yang relatif lama lebih dari 10 hari. Gejala busuk basah pada batang biasanya lebih cepat terlihat jika dibandingkan dengan gejala nekrosis pada daun. Gejala busuk menyebabkan batang menjadi lunak dan basah sehingga tanaman terkulai, sedangkan nekrosis pada daun dapat menimbulkan warna kecokelatan pada bagian yang dilukai. Gejala yang muncul lebih dari 10 hari, biasanya diawali dengan kelayuan atau mengerutnya bagian batang, sehingga batang terlihat berwarna pucat dan lama-kelamaan menyusut. Gejala yang berkembang ke bagian daun dapat menyebabkan daun berwarna pucat dan menggulung.

Gejala yang timbul pada tanaman jabon setelah diinokulasi isolat Colletotrichum sp. yaitu berupa nekrosis yang muncul pada bagian tangkai daun yang dilukai, sedangkan inokulasi yang dilakukan pada batang dan helai daun tidak memperlihatkan gejala. Masa inkubasi untuk menimbulkan gejala yaitu sekitar 7 hari. Gejala yang sudah muncul umumnya tidak berkembang sehingga tanaman tidak mengalami mati pucuk.

Inokulasi isolat Pestalotiopsis sp., Curvularia sp., dan miselium steril tidak menimbulkan gejala. Bagian tanaman dilukai yang dijadikan titik inokulasi mengalami penebalan dan luka akan tertutup kembali. Selain isolat-isolat di atas, inokulasi blok agar yang merupakan kontrol juga tidak menimbulkan gejala penyakit (Gambar 4e).

Hasil reisolasi dari bagian tanaman yang bergejala, tidak hanya diperoleh cendawan yang diinokulasikan, akan tetapi juga cendawan lain. Meskipun demikian, isolat-isolat yang diinokulasikan umumnya dapat direisolasi dari sampel anakan. Sebagian besar isolat yang diinokulasikan dapat menimbulkan gejala, akan tetapi isolat yang dapat menghasilkan gejala identik dengan gejala alami mati pucuk adalah isolat Botryodiplodia spp.

Berdasarkan hasil inokulasi pada rangkain uji postulat Koch dapat diketahui bahwa sebagian besar isolat yang diuji bersifat patogenik terhadap bibit jabon. Meskipun demikian, tidak semua isolat dapat menghasilkan gejala yang identik dengan gejala mati pucuk.
Isolat-isolat Botryodiplodia spp. secara umum menimbulkan gejala pada titik inokulasi (dilukai dan tidak dilukai). Hal ini menunjukkan bahwa cendawan ini dapat memasuki jaringan inang melalui luka atau penetrasi langsung. Berdasarkan pengamatan gejala, inokulasi isolat cendawan Botryodiplodia spp. menimbulkan gejala yang identik dengan gejala alami mati pucuk pada tanaman jabon, yaitu menyebabkan batang jabon menjadi menyusut dan kering serta daun menjadi berwarna kecokelatan dan menggulung. Atia et al. (2003) menjelaskan bahwa cendawan $B$. theobromae yang diinokulasikan pada tanaman anggur, dapat mengakibatkan sel epidermis dan korteks menjadi berwarna coklat tua. Sel mengalami plasmolisis dan kebanyakan sel floem dan xilem mengalami kerusakan.

Masa inkubasi cendawan Botryodiplodia spp. untuk menimbulkan gejala, relatif lebih pendek jika dibandingkan dengan cendawan lainnya. Kondisi ini menunjukkan bahwa Botryodiplodia spp. dapat berkembang dengan cepat dalam jaringan inang. MenurutAtia et al. (2003), hifa $B$. theobromae mudah dan cepat menyebar melalui berkas pembuluh.

Berbeda dengan Botryodiplodia spp., isolatisolat Fusarium spp. hanya menimbulkan gejala pada titik inokulasi yang dilukai. Gejala yang muncul cukup bervariasi, baik bentuk maupun masa inkubasi yang diperlukan. Gejala dengan masa inkubasi pendek biasanya menunjukkan gejala busuk basah, sedangkan gejala dengan masa inkubasi yang panjang umumnya berupa layu atau mengerutnya batang. Meskipun masa inkubasinya berbeda, kedua gejala tersebut dapat menyebabkan kematian pada tanaman.

Berdasarkan penjelasan di atas dapat diketahui bahwa Fusarium spp. memerlukan luka atau lubang alami untuk memasuki jaringan inang. Cendawan yang telah memasuki jaringan inang selanjutnya dapat menghancurkan dinding sel, sehingga jaringan tanaman menjadi lunak. Selain itu, adanya cendawan yang mampu mencapai jaringan pembuluh dapat menyebabkan tanaman menjadi layu. Hal ini terjadi karena adanya penghambatan proses transpotasi air dari akar menuju bagian atas tanaman. Penelitian Atia et al. (2003) menunjukkan bahwa fragmen miselium F. solani dapat ditemukan pada pembuluh xilem tanaman anggur (Vitis vinifera L.) setelah 21 hari masa inkubasi. Cendawan ini menyebar secara intra dan interseluler dalam seluruh jaringan dan pembuluh yang dikolonisasi oleh hifa dan tilosis. 
Gejala layu pada bibit jabon memerlukan masa inkubasi yang lebih lama jika dibandingkan dengan gejala busuk basah. Hal ini menunjukkan bahwa kelayuan pada bibit jabon merupakan gejala laten yang dihasilkan oleh Fusarium spp. yang selanjutnya berkembang menjadi mati pucuk. Atia et al. (2003) menyatakan bahwa munculnya gejala mati pucuk bisa jadi dikarenakan adanya nekrosis pada pembuluh, adanya hifa cendawan, induksi badan inklusi, dan tilosis yang menyebabkan tidak berfungsinya pembuluh xilem dan terganggunya aliran air.

Isolat Colletotrichum sp. dapat menimbulkan gejala nekrosis pada bagian tangkai daun, namun nekrosis tidak berkembang. Meskpiun demikian, hal ini perlu diperhatikan karena menurut Anggraeni (2009) gejala nekrosis oleh Colletotrichum pada tanaman rentan dapat menyebabkan mati pucuk atau kematian total terhadap bibit jabon.

Sering munculnya beberapa macam cendawan pada bibit jabon yang terserang mati pucuk, menunjukkan bahwa penyakit ini bisa disebabkan oleh 1 atau beberapa macam cendawan. Cendawan yang mampu menghasilkan gejala mati pucuk dengan inokulasi tunggal dapat diduga sebagai penyebab primer, sedangkan cendawan lainnya merupakan penyebab sekunder. Saeed et al. (2011) menyatakan bahwa cendawan patogen bisa menjadi lebih virulen ketika dikombinasikan dengan cendawan lain, namun dalam penelitian ini, uji Postulat Koch dilakukan melalui inokulasi secara tunggal. Oleh sebab itu, hubungan antara satu cendawan dengan cendawan lainnya tidak diketahui.

Cendawan yang telah diinokulasi pada tanaman jabon, secara umum dapat direisolasi dari tanaman jabon yang menunjukkan gejala. Berdasarkan uji postulat Koch, cendawan yang diduga sebagai penyebab primer dari gejala penyakit mati pucuk pada bibit jabon adalah Botryodiplodia spp.

\section{KESIMPULAN DAN SARAN}

\section{A. Kesimpulan}

Isolat cendawan yang berhasil diperoleh dari tanaman jabon dengan gejala mati pucuk yaitu sebanyak 25 isolat. Berdasarkan karakter morfologi isolat-isolat tersebut merupakan Botryodiplodia spp., Fusarium spp., Colletotrichum sp., Curvularia sp., dan Pestalotiopsis sp. Isolat yang diduga sebagai patogen penyebab primer penyakit mati pucuk pada bibit jabon adalah Botryodiplodia spp.

\section{B. Saran}

Pembibitan tanaman jabon sebaiknya dilakukan bersama dengan tanaman lain agar ketersediaan inang bagi patogen lebih beragam. Selain itu, kerusakan fisik dan kondisi stres tanaman perlu diminimalisir untuk mencegah atau mengurangi gangguan penyakit, khususnya mati pucuk.

\section{UCAPAN TERIMA KASIH}

Penulis mengucapkan terima kasih kepada teman-teman dan rekan-rekan di Laboratorium Mikologi, Departemen Silvikultur, Institut Pertanian Bogor, serta seluruh pihak atas bantuan dan dorongan yang diberikan selama proses penelitian dan penyusunan tulisan. Semoga dicatat sebagai amal kebaikan.

\section{DAFTAR PUSTAKA}

Ahmad, I., Khan, R.A., \& Siddiqui, M.T. (2012). Incidence of dieback disease following fungal inoculations of sexually and asexually propagated shisham (Dalbergia sissoo). For. Path., 43, 77-82. Akses tanggal 30 Oktober 2012, dari http://onlinelibrary. wiley.com/doi/ 10.1111/efp.12001/pdf.

Akrofi, A.Y., \& Amoah, F.M. (2009). Pestalotia spp. causes leaf spot of Vitellaria paradoxa in Ghana. Afr.J.Agric.Res., 4(4), 330-333. Akses tanggal 7 Maret 2013, dari http://www.academicjournal.org/article/article 1380793191_Akrofi and Amoah.pdf.

Anggraeni, I. (2009). Colletotrichum sp. penyebab penyakit bercak daun pada beberapa bibit tanaman hutan di persemaian. Mitra Hutan Tanaman, 4(1), 29-35. Akses tanggal 9 Februari 2012, dari http://forplan.or.id/images/File/ Mitra/MITRAHT Vol4 No1 th 2009.pdf.

Atia, M.M.M., Aly, A.Z., Tohamy, R.M.A., El-Shimi, H., \& Kamhawy, M.A. (2003). Histopathological studies on grapevine die-back. Journal of Plant Diseases and Protection, 110(2), 131142. Akses tanggal 19 Juni 2012, dari http://www.jpdponline.com/artikel.dll/200302-s131-142-atia-histo_NTc3NJA.PDF.

Barnet, H.L., \& Hunter, B.B. (1998). Illustrated genera of imperfect fungi. $4^{\text {th }}$ ed. Minessota: APS Press.

Douglas, S.M. (2009). Combating plant diseases in the nursery. New England Grows. New England. Akses tanggal 7 Juli 2012, dari http://www.newenglandgrows.org/handouts/ 2009/SharonDouglasHandout.pdf. 
Ismail, A.M., Cirvilleri, G., Polizzi, G., \& Crous, P.W. (2012). Lasiodiplodia species associated with dieback disease of mango (Mangifera indica) in Egypt. Australasian Plant Pathol, 41, 649660. Akses tanggal 21 Februari 2013, dari http://www.plant managementnetwork.org/ pub/php/diagnostic guide/2004/mango/.

Khanzada, M.A., Lodhi, A.M., \& Shahzad, S. (2004). Mango dieback and gummosis in Sindh, Pakistan Caused by Lasiodiplodia theobromae. Akses tanggal 22 Februari 2013, dari http://www.plantmanagement network.org/pub/php/diagnosticguide/2004/ mango/.

Kirisits, T., Kritsch, P., Kräutler, K., Matlakova, M., \& Halmschlager, E. (2012). Ash Dieback Associated with Hymenoscyphus pseudoalbidus in Forest Nurseries in Austria. J.Agric.Ext. Rural.Dev., 4(9), 230-235. Akses tanggal 10 Februari 2014, dari http://www.academicjournals.org/article/article1379689263_Kirisits et al.pdf.

Mansur, I., \& Tuheteru, F.D. (2010). Kayu jabon. Jakarta: Penebar Swadaya.

Muehlbach, H.P., Tantau, H., Renk, S., Schultz, D., Woelki, S., Meyer, H., Schulze, J., et al. (2010). Molecular detection and characterization of biotic agents associated with dieback disease of Dalbergia sissoo Roxb. in Bangladesh. dalam: Islam AS et al., editor. Role of biotechnology in food security and climate change. Proc. Sixth Intl. Plant Tissue Cult. \& Biotech, 2010 Desember 3-5; Dhaka. Bangladesh Assoc. Dhaka: Plant Tissue Cult. \& Biotech. p. 131-143.

Novaes, E., Kirst, M., Chiang, V., Sederoff, H.W., \& Sederoff, R. (2010). Lignin and biomass: A Negative correlation for wood formation and lignin content in trees. Plant Physiol, 154, 555561. Akses tanggal 22 Oktober 2013, dari http://www.plantphysiol.org/content/154/2/55 5. full.pdf + html.
Rahman, M.A., Baksha, M.W., \& Ahmed, F.U. (1997). Diseases and pests of tree species in forest nurseries and plantations in Bangladesh. Bangladesh Agricultural Research Council. Dhaka. Akses tanggal 21 Januari 2013, dari http://mapbangla.com/mapadmin/publica tion/149 040 Diseases and pests of tree species in forest nurseries and plantations in Bangladesh.pdf.

Rajput, N.A., Pathan, M.A., Jiskani, M.M., Rajput, A.Q., \& Arain, R.R. (2008). Pathogenicity and host range of Fusarium solani (Mart.) Sacc. causing dieback of shisham (Dalbergia sissoo Roxb.). Pak J Bot, 40(6), 2631-2639. Akses tanggal 20 November 2012, dari http://(6)/ PJB40(6)2631.pdf.

Saeed, S., Khan, M.I., \& Masood, A. (2011). Symptom development after artificial inoculation of Botryodiplodia theobromae, a possible causal organism to quick decline in mango trees. Pak.J.Agri.Sci., 48(4), 289-294. Akses tanggal 28 Juni 2012, dari http://pakjas.com.pk/ papers|1960.pdf.

Safriati. (2012). Respon pertumbuhan jabon terhadap sumber benih dan dosis pupuk yang berbeda pada daerah bekas tambang batubara di PT Kaltim Prima Coal, Sangatta, Kalimantan Timur. Skripsi. Tidak dipublikasikan. Fakultas Kehutanan: Institut Pertanian Bogor.

Sinaga, M.S. (2006). Dasar-dasar ilmu penyakit tumbuhan. Jakarta: Penebar Swadaya.

Watanabe, T. (1994). Pictorial atlas of soil and seed fungi morphologies of cultured fungi and key to species. London: CRC Press Inc.

Widyastuti, S.M., Sumardi, \& Harjono. (2005). Patologi hutan. Yogyakarta: Gadjah Mada University Press.

Wiguna, I., \& Yajri, F. (2010, Juli). Berpacu kejar kayu lapis. Trubus. Topik. p. 18-19. 